\title{
The Role of Indonesian School Principals' Leading Distance Learning During Covid-19 Pandemic
}

\author{
Yoni Nurdiansyah* \\ INSPIRASI Foundation \\ Jakarta, Indonesia \\ *ynurdian@inspirasifoundation.org
}

\begin{abstract}
The focus of this study is to investigate how the principal leading distance learning during this pandemic. The aims are to get a comprehensive result of how the principal aware of the concept of distance learning and what challenges they faced during the process. A qualitative research approach was employed in this study to get a deep understanding and explanations from the participants. The participants are twentyfive school principals from different primary schools under the Ministry of Education and Ministry of Religious Affairs in Karawang district, Indonesia. It was revealed that school principals in this study were having only a limited idea about the concept of the distance learning model. They were aware of how distance learning works, even when they have only limited knowledge and skill. Principals mentioned about skills and knowledge that principals needed most in leading during the distance learning, such as providing advice on designing interesting activities for teachers, skills in operating educational applications, implementing multiple distance learning models/strategies, accessing information from the various online sources, doing the academic supervision, providing training related to online learning for teachers, and managing the wellbeing of teachers and students. School principals in this study responded that they faced multiple challenges during distance learning implementation. The four most common ones were their concern around the online teaching model, distance learning infrastructures, teachers' basic qualifications explicitly oriented to technology, and adjusting the offline curriculum materials into an online model.
\end{abstract}

Keywords-COVID-19 pandemic, education, leading distance learning, online learning, school principal

\section{BACKGROUND}

Since early 2020, the sudden outbreak of Corona Virus (SARS-CoV-2) called Covid-19 shook the entire world. This circumstance contested the education sector and educators were demanded to change their delivery model to online learning in just a second. It happened unexpectedly, and most of the educators were not ready for the conditions. The use of technology in education certainly cannot be ignored since it has improved access, improved efficiency, and the quality of learning and teaching. Desai [1] asserts that technology in education provides schools with resources, information, communication, interactive learning, and enhanced education change. In the past, classrooms were more likely lecture driven, and teachers are the ones who would provide all kinds of resources. Today, teachers do not play a role as a central source of learning and information, but more to be a facilitator, a companion, a mentor, and a partner in developing skills and knowledge [2]. The introduction of distance learning in education during this pandemic would help students in the classroom to be more engaged in the learning process. Teachers would no longer be the center of attention; instead, students can be more active, self-independent, and studentcentered. Students can have choices on how they can obtain, generate, or present the information. By doing this, students may likely to succeed during studying from home and would have a higher confidence level.

It is a silver lining that technology in education has been found to positively affect a student's learning process towards academic outcomes [3]. When technology and suitable teacher's teaching methods are combined, technology will have a tremendous effect on education. UNESCO [4] assert that "technology in education has become, within a short time, one of the basic building blocks of modern society" and it is vital in "mastering the basic skills and concepts of technology as part of the core of education, alongside reading, writing, and numeracy."

The challenging process of integrating technology in the learning process during this pandemic is in a demanding need for school principals to implement appropriate distance learning technology effectively in their school. According to Flanagan and Jacobsen [5], there are several of things that contributed to the ineffective of technology integration in schools such as school principal's vision and belief toward distance learning technology integration, lack of vision in school as an organization in supporting the technology integration in the learning activities, lack of funding resources, and teacher's expertise towards distance learning technology. Albugami and Ahmed [6] assert that many school leaders still have limited knowledge and capabilities to use the technology in learning practices successfully in integrating technology in instructional practices. Hayes [7] suggests that to successfully implement distance learning, it needs support from the school leader. In this context, school leaders need to be empowered and have prior appropriate competence abilities, skills, and 
potentials that technology offers in education. Even when school is supported by enormous resources and advantages that would help integrate technology in distance learning, without the direct support and values from the school principal, this benefit cannot be directed to its full potential.

It is generally believed that the quality of teaching and learning shall be placed as the first substantial effort of all those in leadership roles in schools. As a pedagogical leader, the school principal beliefs and attitudes in implementing the distance learning model can significantly influence the effectiveness of the teaching and learning process during the COVID-19 pandemic. Using appropriate educational applications and learning platforms would bring benefits to students in immediate and long-term results, and it is widely known that school principals need to lead on board and drive that effort to happen.

Hargreaves [8] asserts that when school returns to normal, the principal will have to accept that technology has helped and radically changed the learning process. With distance learning on a daily basis, the school leadership has drastically and hopelessly moved. However, it remains a crucial and major force in maintaining the school system moving [9]. Principals are now secluded leaders, far away from teachers and staff they lead. Separated from the students in distance. These are tough, unusual, bizarre, and unforeseeable condition for principals. Therefore, well-being of the principals is one of the priorities they must have in order to make them remain in good health to pillar the members of the school. Parental and community leadership become progressively essential because leading distance learning required help and support from parents and the community around the school.

\section{METHODS}

The focus of this study is to investigate how the principal leading distance learning during COVID-19 pandemic. The researcher employed a qualitative approach. It was correlated with the researcher's aims to explore the state of school principals' attitudes and act in human behaviour within the context of distance learning and the challenges they work within. The participant in this study were Twenty-five school principal in Karawang District. The researcher particularly carried out an interview as a single and primary data collection. Among the three kinds of interviews in the research process, the researcher purposely uses a semi-structured interview to allow the researcher to get more understanding and knowledge from the participant by providing an opportunity for the researcher to expand participant responses. The authentic data taken from the field were organized, read through, categorized, identified and sorted into several categories to reach generalized conclusions.

\section{SAMPLING}

The participants for this study were selected using a purposive sampling method, which selects only particular participants who can present valuable information [10]. The participants were school principals who are selected in their capabilities related to the topic. Twenty-five school principals from different primary schools under the Ministry of Education and Ministry of Religious Affairs in Karawang district, Indonesia, were chosen to participate in this study. The selection of participants for this study was based on several criteria such as (1) their experiences leading school, (2) their availability to be part of the research. For the first criterion, the researcher chose them because their insight would be expected to give a better understanding of the way school principals embracing technology in the classroom since they are in a leadership position for several years. With regard to the second, all of those participants were willingly agreed to be interviewed.

\section{ETHICS}

It is essential and necessary for all research to be ethical and responsible. Since the research involves human beings, there are some essentials ethical considerations that need to pay attention to. Therefore, this study is only done with regard to ethical respect for participants and their knowledge. In line with standard ethical procedures, the researcher does not use any participant details, including name, gender, religion, and age, that would reveal any identification to keep the participant's confidentiality.

\section{THEORETICAL FRAMEWORK}

The technology in today's' digitalize world has become an essential requirement in supporting the effectiveness and quality of education. According to Desai [1], technology can reduce space and time constraints to retrieve, move, analyse, present, store, and pass information data into information. In the learning context, the technology covers all things connected to the utilization of computers to process information, use it as a learning tool, and provide a source of information for teachers and students. Pelgrum and Law [11] assert that there are several potential positive effects in using online technology in education, such as providing more effective access to education, enhancing efficiency, and, most importantly, improving the learning process's quality. The 21 st century is a digital era where communication comes across borders' barrier. The use of technology in education would provide availability of information anywhere and anytime (information), the implementation of the use of machines (computing), able to reach all the work routine and can be done from anywhere (communication)

Mingaine [12] asserts that to successfully implemented distance learning, school as an organization needs to embed the vision in school culture and the school leader needs to have visionary short-term and long-term plans in school they work with. Without those strategic plans embedded in school culture, there will be a lack of coordination and only several interested school members that would struggle to support online learning integration in learning activities. Gurr [13] asserts that in implementing the use of technology in learning, school leaders need to show and be able to operate some basic technical 
knowledge to work successfully in integration and inspire all school members to implement it. By having some basic knowledge and skills, the school leader would show to the school members that its technology integration is essential, and the school leader positioned themselves as role models.

The implementation of technology integration in learning activities has not developed optimally in Indonesia. One obstacle to technology integration is that teachers' and school leaders' expertise related to its concept is still low [14]. Much research supports the argument that the school principal's attitude, view, and behaviour influence a school's success in implementing distance learning activities [15]. Schiller [16] asserts that the school principal's view of online learning is essential. He also stated that educational leaders' attitudes and views have a significant influence on the integration process's success. In schools, mainly school principals' attitudes, views, and behaviour toward online learning would show how they regularly use in daily teaching and reassuring all school members to use it. School principals with fewer attitudes toward online learning are less likely to implemented or even supported it. Mingaine [11] asserted that the school principals' role is vital in creating a school environment that was supporting school members to work effectively during online learning.

The implementation of distance learning in a school setting is sometimes complicated and challenging. It requires funds, infrastructures, adequate teachers and staff, and other technical supports [10]. Sinko, as cited in Sabaliauskas and Pukelis [17], asserts of some challenges in using educational technology in learning such as; "lack of support for the educational personnel and learners, lack of teacher competencies to use certain software, insufficient financing (of teacher professional developments in the technology field, of appropriate device hardware and software, etc.), lack of cooperation among academic personnel in the same and another school."

\section{RESEARCH FINDINGS AND DISCUSSION}

\section{A. School Principals' Awareness of the Concept of Distance Learning}

School principals responded to have little ideas in the implementation and how distance learning works. Never received or took part in any technology-related training before or during the pandemic. Having basic technology competency but in the practical level of use. There are currently several typical mobile phone applications that they were using confidently by self-study such as WhatsApp, Gmail, zoom meeting and social media applications. Before COVID-19 they also used technology mostly for administrative purposes. It included the following tasks: communicating with stakeholders via WhatsApp, managing and revising the school budgets called $R A K S$, reviewing lesson plan, creating PowerPoint presentations, $\log$ in into government based education websites, and reading and posting messages on social media.
Principals appeared to have a favourable view of how the online learning model can help the student in the future when the COVID-19 pandemic is over. Principals believed that technology had a positive effect and is a part of a $21^{\text {st }}$ century education even if there was not Coronavirus. Principals in this study strived to assure their teachers and students having an appropriate distance learning device such as mobile phone, credits, and other technological devices. Even though they continued to face challenges in getting funds to support teachers in distance learning. It was mentioned that there some skills and knowledge that principals needed most in leading during the distance learning, such as providing advice on designing interesting activities for teachers, skills in operating educational applications, implementing multiple distance learning models/strategies, accessing information from various sources, doing the academic supervision, providing training related to online learning for teachers, and managing the wellbeing of teachers and students (See Figure 1).

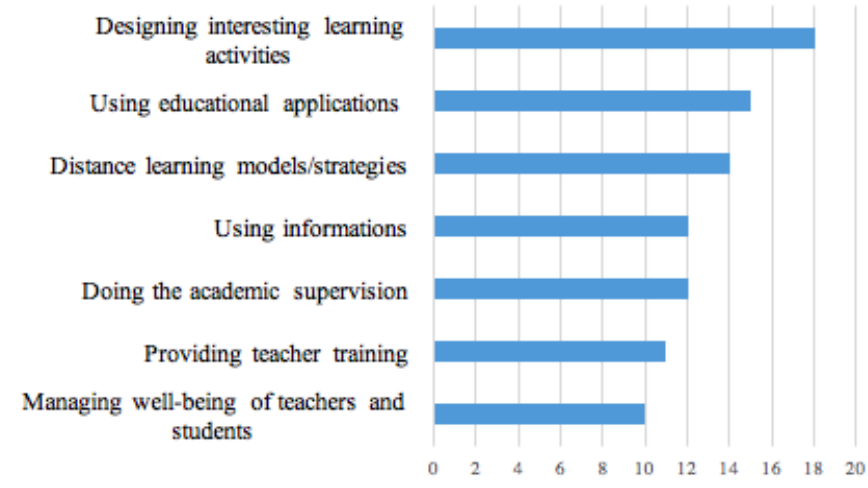

Fig. 1. School principals' response to skills and knowledge that they needed during distance learning.

Principals asserted that the introduction of technology in education would benefit the school in creating a studentcentered learning process. Several principals mentioned that distance learning is heavily influenced by various elements, including their knowledge and skills related to technology, infrastructures provided, school culture and environment, and, most importantly, teacher's motivation. In COVID-19 times, principals assured that the teacher chooses a limited number of learning tools to use and provides access to them. They also determine how many teachers and students have no access to the internet and decide the most appropriate learning model for them. However, only a few principals work with teachers directly to develop clear learning plans so that students feel like they are getting what they need without being overwhelmed. In finance-related, the principal reallocates the current budget toward COVID-19 priorities.

\section{B. School Principals' Challenges During Distance Learning}

There are several obstacles revealed in the implementation of distance learning. Principals stated that their teachers had difficulty adjusting the offline curriculum materials into the online model. Teacher's ability to run the distance learning 
process is still limited. It was due to a lack of training and preparation. Severe concern about insufficient support related to distance learning during this pandemic was also mentioned. Online learning requires mastery of information technology in education and how to bring comfort and happiness to students in learning activities. Several principals were afraid of failing when using the online learning model. So that they preferred to switch to an offline model called luring. Most schools are currently using those two kind model of learning delivery.

Principals put massive concern toward teacher's ability on how integrating the online learning model into pedagogical practice. They believed that technology integration would be successful when teachers have some basic qualifications explicitly oriented to technology. They stated lack of teacher competencies directly affects teacher self-confidence as teachers feeling afraid of implementing an online learning model. Lacking the knowledge and skills would also affect the teacher enthusiasm about the online learning model as they would likely resistance to change. The principals in this study were also asked about what support they provided to teachers in overcoming those challenges. Most principals initiated peer support, where teachers collaborated to share best practices based on understanding and experience teaching in an online model. Other obstacles experienced by principals during pandemic include teachers and students not having the necessary equipment (e.g., mobile phones, laptops, tablets), limited internet access, and limited skill in using online learning platforms. Principals mentioned that the teacher's English ability also became another influential factor contributing to distance learning. Most of the internet-based educational materials available are likely in English. English is the largest language to be used on most learning apps and online content for education. It is correlated with Mitra and Dangwal [18] that those who have English ability would do better in a self-organizing learning system. For developing countries such as Indonesia, where English fluency is not high, this is a severe challenge to maximizing technology benefits for education.

\section{CONCLUSION AND RECOMMENDATION}

It is widely concerned that the quality of learning shall be placed high as a core and pivotal goal of all who are entitled to a leadership role in schools. School principals are the important educational leaders, and their attitudes, visions, views, knowledge, and behaviour, toward the implementation of distance learning, can significantly influence how far the effectiveness of learning. The sudden outbreak of the Corona Virus (SARS-CoV-2) called Covid-19 impacted education significantly. Implementing a distance learning mode has promoted schools' changes to shift from the old teaching methods to learning to the new one. School principals have a significant influence in school and should look for the most effective ways to implement and lead distance learning. The role of technology is become critical and can no longer be ignored. However, the effectiveness of distance learning is strongly influenced by the school principal's ability to lead and manage all school components. This study showed that school principals are aware of how distance learning works, even when they have limited knowledge. Their understanding of distance learning is likely in the practical use area. School principals in this study mentioned that they faced multiple challenges during distance learning implementation. The four most common ones were their concern around the online teaching model, distance learning infrastructures, teachers' basic qualifications explicitly oriented to technology, and adjusting the offline curriculum materials into an online model. Several recommendations include the need to structure support to school principals based on their biggest concerns and challenges. To connect school principals in peer groups under the school principal working group "kelompok kerja kepala sekolah" - provide them with support to share some of the best practices and experiences as some of them are currently being more innovative and resourceful during this pandemic time. Maintain connection with teachers, students and parents to understand their needs. School principals can work with teachers to make sure the teacher has checked in with every student whether by phone or by word of mouth to assure student's well-being

\section{REFERENCES}

[1] S. Desai, "Role of information communication technologies in education," Proceedings of the 4th National Conference, pp. 25-26, 2010 .

[2] M.F. Mascolo, "Beyond Student-Centered and Teacher-Centered Pedagogy: Teaching and Learning as Guided Participation," Pedagogy and the Human Sciences, vol. 1, no. (1), pp. 3-27, 2009.

[3] S. Mbugua, J. Kiboss, and E. Tanui, "Influence of Integration of Information Communication Technology in Teaching on Students Academic Performance," Journal of Education and Practice, vol. 6, no. (24), pp. 7-13, 2015

[4] UNESCO, Information and Communication Technology in Education: A Curriculum for Schools and Program of Teacher Development. UK UNESCO, 2002.

[5] L. Flanagan and M. Jacobsen., "ICT Implementation and School Leadership: Case Studies of ICT Integration in Teaching and Learning,' Journal of Educational Administration, vol. 41, no. (2), pp. 158-170, 2003.

[6] S. Albugami and V. Ahmed, Towards Successful Implementation of ICT in Saudi Schools (Literature Review). UK: University of Salford, 2015.

[7] D. Hayes, "Making all the Flashy Stuff Work: The Role of the Principal in ICT Integration," Cambridge Journal of Education, vol. 36, no. (4), pp. 565-578, 2006 .

[8] A. Hargreaves, "What's next for schools after coronavirus? Here are 5 big issues and opportunities," The Conversation, 2020. [Online]. Retrieved from: https://theconversation.com/whatsnext-for-schoolsafter-coronavirus-here-are-5-big-issuesand-opportunities-135004 [Accessed on: 19 October 2020).

[9] A. Harris, "COVID-19 - school leadership in crisis,?," Journal of Professional Capital and Community, 2020. Available at: https://doi.org/10.1108/JPCC-06-2020-0045

[10] J.A. Maxwell, Qualitative Research Design: An Interactive Approach. US: SAGE Publications, 2012 
[11] W. Pelgrum and N. Law, ICT in Education Around the World: Trends, Problems and Prospects. UK: UNESCO International Institute for Educational Planning, 2003.

[12] L. Mingaine, "Leadership Challenges in the Implementation of ICT in Public Secondary Schools, Kenya," Journal of Education and Learning; vol. 2, no. (1), pp.32-42, 2013.

[13] D. Gurr, "The impact of Information Communication Technology on the Work of School Principals," Learning and Managing, vol. 6, no. (1), pp. 63-67, 2010.

[14] B. Setiawan and Purnomo,, "Pelatihan Pembelajaran Multimedia," E WARTA, vol. 19, no. (1), pp. 64-73, 2016
[15] S. Hennessy, Developing the Use of Information and Communication Technology to Enhance Teaching and Learning in East African Schools: Review of the Literature. Centre for Commonwealth Education, 2010.

[16] J. Schiller, "Surfers or Spectators? Principals and ICT," Principal Matters Journal, vol. 5, pp. 30-41, 2011 b.

[17] T. Sabaliauskas and K. Pukelis, Barriers to Integration of Information and Communication Technologies into the Teaching and Learning Process. Paper Presented at the European Conference on Educational Research, University of Crete, 2004.

[18] S. Mitra and R. Dangwal, "Limits to self-organising systems of learning - the Kalikuppam experiment," British Journal of Educational Technology, vol. 41, no. (5), pp. 672-688, 2010. 